\title{
Pre and postharvest practices for quality improvement of table grapes (Vitis vinifera L.)
}

\author{
W.A. Harindra Champa \\ Research and Development Centre, Institute of Postharvest Technology, Jayanthi Mawatha, Anuradhapura.
}

\begin{abstract}
Table grapes (Vitis vinifera L.) rank fourth in the world fresh fruit production after citrus, bananas and apples. In Sri Lanka, grapes are grown in an area of about 100 ha. It is one of the main fruits imported to the country and according to Sri Lanka Customs, 5.1 million $\mathrm{kg}$ of grapes worth Rs. 1.1 billion were imported in the year 2012. These imports can be significantly reduced as there is ample scope to produce grapes locally in the land available in the North and East of Sri Lanka. The crop thrives well in these Dry Zone areas having well drained deep soils with assured irrigation. Dry weather during flowering, fruit development and maturity is essential for the production of quality grapes. Unlike other fruit crops, proper pruning of vines at the correct time is mandatory to stimulate fruiting. In order to produce a quality bunch of grapes, there are many practices that viticulturists must be aware of. This article is based on the author's three-year experience at a vineyard situated in the Punjab Agricultural University, Ludhiana, Punjab, India. The paper discusses preharvest and postharvest practices that should be adopted for producing high quality table grapes, along with recent research advances on the role of plant growth regulators in quality improvement.
\end{abstract}

Keywords: Brassinosteroids, polyamine, preharvest and postharvest practices, pruning, salicylic acid, viticulture.

\section{INTRODUCTION}

Viticulture is one of the major horticultural industries in the world and is practiced on an estimated area of 6,969,373 ha (FAOstat, 2012). Approximately, $71 \%$ of the world's grape production is used for wine, $27 \%$ as fresh fruit and $2 \%$ as dried fruit (raisins). Table grapes rank fourth in world fresh fruit production after citrus, bananas and apples. China is the world's largest grape producer having an annual production of 9.6 million tonnes (FAOstat, 2012), followed by USA, Italy, France and Spain. In Sri Lanka, grapes (Vitis vinifera L.) are grown in an area of about 100 ha (Anon, 2010a) and according to Sri Lanka Customs, 5.1 million $\mathrm{kg}$ of grapes worth Rs. 1.1 billion were imported to the country in the year 2012. Such costly imports can be significantly reduced, if the potential for domestic production is realized and the land available in the North and East of Sri Lanka is utilized for the production of this crop.

Grapes are rich in polyphenolic phytochemical compounds such as resveratrol, anthocyanins and other phenolics, which are powerful antioxidants that can reduce the damage caused by free radicals. They are known to play a protective role against colon and prostate cancer, coronary heart disease, degenerative nerve disease and viral/ fungal infections. In addition, grapes are rich in vitamins $\mathrm{A}, \mathrm{C}$, pyridoxine $\left(\mathrm{B}_{6}\right)$, folate and essential minerals such as potassium, calcium, iron, phosphorus, magnesium and selenium. Local grapes can meet the nutritional and health requirements of Sri Lankans, if the commodity is readily available and affordable for the average Sri Lankan citizens.

The quality of grape berries is the prime consideration in both domestic and export markets. Grape berries develop as clusters with each berry attached to the bunch stem (rachis and branches) via a pedicel, which contains vascular bundles. The important quality characteristics comprise both bunch as well as berry properties. These include uniform bunch colour, bunch size, bunch shape and weight, stem quality, berry colour, berry size and shape, firmness, total soluble solids (TSS), titratable acidity (TA), antioxidants (anthocyanins, phenols) and sugar acid blend that determines the flavour. This article will focus on the recent technological and research advances pertaining to improve and maintain table grape quality. 


\section{Preharvest practices to improve bunch and berry quality}

Climate/environment and cultivar selection: Grapes can be grown commercially in climates ranging from temperate to tropical. It is therefore one of the world's most widely distributed fruit crops. In Sri Lanka, the crop can be grown in the Dry Zone, in lands having well drained deep soils with assured irrigation. Dry weather during flowering, fruit development and maturity is essential for the production of quality grapes. If the rainy season coincides with the harvesting period, it results in cracking of berries, increasing decay incidence and reduction in sugar acid blend, leading to heavy losses.
Suitable varieties for cultivation should be selected based on the compatibility with local climate and end use i.e table purpose or for the production of wine, juice or dried grapes (raisins). According to present crop recommendations by the Department of Agriculture, Sri Lanka, there are three table grape varieties, namely, Israel Blue, Cardinal (pink colour) and Black Muscat. The variety Muscat MI, which produces dark purple medium size berries is usually recommended for red wine, but it can also be used as a table variety. French MI produces light green berries and is recommended for white wine production. The world's leading grape cultivars classified based on the uses are given in Table 1.

Table 1: Classification of world's leading grape cultivars based on the use

\begin{tabular}{lll}
\hline Table grapes & Wine or juice production & Dried grape production \\
\hline $\begin{array}{l}\text { Italia (Muscat), Chasselas } \\
\text { Muscat de Hambourg }\end{array}$ & Pinot noir, Merlot & Black Corinth \\
Alphonse Lavalle & Cabernet Sauvignon & Thompson Seedless \\
Regina Bianca, Perlette & Punjab Purple & Sultana \\
Ruby Seedless & Bangalore Blue & Kishmish Rozavis White \\
Thompson Seedless & Chardonnay & A18-3 \\
Flame Seedless & Riesling & E12/7, E12/3 \\
Crimson Seedless & Sauvignon Blanc & \\
Autumn Royal & Chenin Blanc & \\
2- A clone of Thompson Seedless & Muller Thurgau & \\
Anab-e-Sahi, Tas-e-Ganesh & Chasselas & \\
Sonaka, Manik & Semillon & \\
Sharad Seedless & Palomino & \\
Red Globe, A17-3 & Shiraz & \\
& Grenache & \\
\hline
\end{tabular}

Source: Anon (2012).

Training and pruning: To produce high quality fruits from the vines, the training system and variety based pruning play a critical role. The training system affects the exposure of vines to sunlight thus improving vine productivity, hastening berry maturity, developing uniform bunch colour, lowering disease incidence and increasing sugar acid blend. There are numerous training systems used all over the world, namely, kniffin, telephone, head, Geneva double curtain, fence system, bower and $Y$ trellising etc. (Creasy \& Creasy, 2009). The Y system of training (Figure 1) is quite new and is becoming popular in places like Northern India due to several reasons such as 2-3 days early fruit maturity, better fruit quality, and lower incidence of fungal diseases like anthracnose and powdery mildew thus lower chemical residues due to lesser frequency of spraying fungicides and insecticides (Anon, 2010b). Since the branches of this system are at the average height it facilitates ease of carrying out fruit quality improvement practices such as cluster thinning, flower bud thinning, gibberrellic acid (GA3) dips and girdling (Gill \& Arora, 2007).

Since the grapevine is naturally a deciduous type woody climbing vine, regular annual pruning is mandatory. During the process of pruning, almost $50 \%$ of the shoots developed in a year are removed (Gill \& Arora, 2007). One year old mature shoots are called the canes. Cane pruning is done retaining $3-4$ buds/cane and is termed as fruiting canes. About $60-80$ canes per vine distributed evenly in the canopy area are retained every year after pruning. Along with the fruiting canes, almost an equal number of shoots having only $1-2$ buds (spurs) are also retained on a vine, so that in a given season the fruiting canes will bear bunches and the spurs will develop into vegetative shoots, which act as fruiting canes in the next season. In this way, the potential of vines to yield uniform fruits over the years is retained (Gill \& Arora, 2007). 


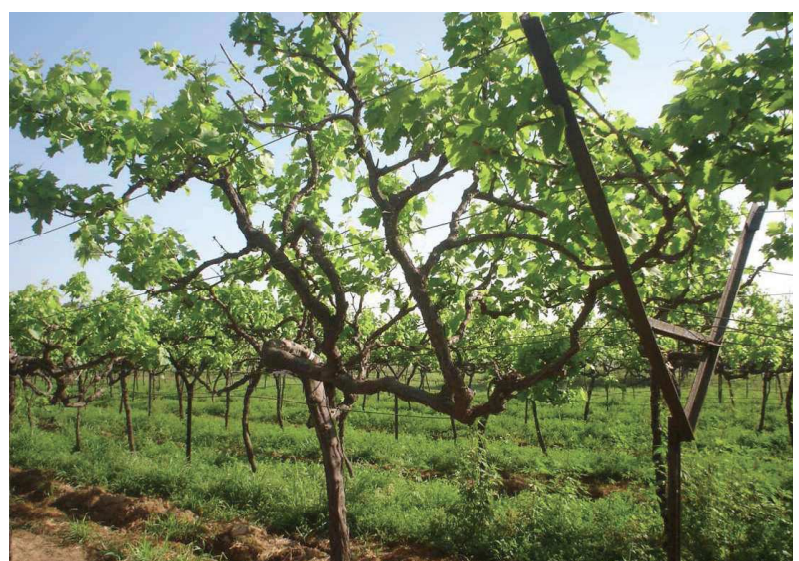

Figure 1: Y system of training

Cluster and flower bud thinning: In order to get bunches having large and uniform berry size, maintenance of $75 \%$ crop load ( $80-90$ bunches/vine) is important especially in varieties that bear profusely. For that, thinning of flower clusters leaving 80 - 90 clusters per vine should be done just after bunch emergence (Anon, 2010b). In varieties that produce compact bunches, thinning of flower buds leaving $100-120$ flower buds per panicle $\left(1 / 3^{\text {rd }}\right.$ is retained and the rest is removed) should be carried out one week prior to blooming, with the aid of a specially designed soft brush (Figure $2 \mathrm{~b}$ ). Through this practice, it is possible to get the typical shape of a grape bunch with larger berries (Gill \& Arora, 2007).

Girdling and GA3 treatment: Once the berry size attains $4 \mathrm{~mm}$ (diameter), removing a $2 \mathrm{~mm}$ wide ring of the bark from the main stem will enhance the berry size
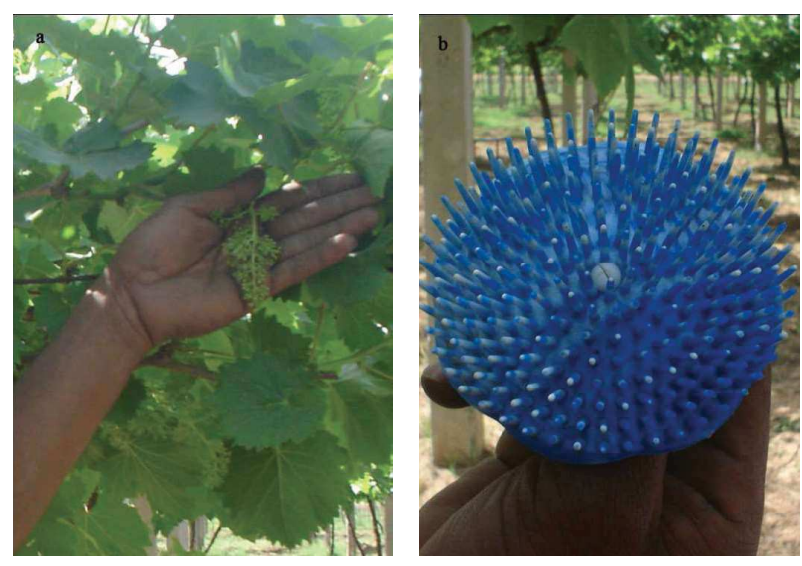

Figure 2: Flower cluster ready for flower bud thinning (a) and the brush used for thinning (b) further and hasten maturity. Gibberrellic acid (GA3) is a plant hormone mainly responsible for cell elongation (Taiz \& Zeiger, 2010). Therefore, to increase stalk length of the varieties that produce compact bunches, dipping the clusters in $40 \mathrm{mg} / \mathrm{L} \mathrm{GA} 3$ solution when the berries are at $4 \mathrm{~mm}$ size is recommended (Anon, 2010b). This treatment alleviates bunch compactness thus allowing the berries to grow larger.

Maturity, colour and ripening enhancers: Spraying of growth regulators such as ethephon (an ethylene releasing compound - 2-chloroethyl phosphonic acid) at a concentration of $400 \mathrm{mg} / \mathrm{L}$ at colour break stage has been established as a routine cultural practice among viticulturists to hasten maturity and to get uniform bunch colour (Roberto et al., 2012). However, the concentration commonly needed for colour improvement often reduces fruit firmness (Peppi et al., 2006; 2007) and also increases berry shatter (Amiri et al., 2009; 2010) during the subsequent postharvest period, since ethylene is the primary trigger of the abscission process (Taiz \& Zeiger, 2010).

For the above reasons, many of the grape growing countries use abscisic acid (ABA) as an alternative to ethephon to advance berry maturity and to promote uniform colouration, especially in red table grapes.

\section{Role of preharvest sprays on the quality of berries}

Brassinosteroids: Symons et al. (2006) have suggested that brassinosteroids (BRs), a group of steroidal plant hormones essential for normal plant development, may influence the process of grape berry ripening. A clear pattern of changes in the expression of genes controlling BRs synthesis and endogenous levels, which coincide with the onset of ripening have been observed. A dramatic increase in the levels of bioactive BRs - castasterone (CS), and its direct precursor 6-deoxocastasterone have been observed between 8 and 10 weeks post flowering (13 and 9 fold, respectively). This change coincided with the onset of ripening as indicated by the increase in berry weight and TSS content, which also occurred at this stage. Champa et al. (2014a) have reported that foliar treatment of BRs at a dose of $1 \mathrm{mg} \mathrm{L}^{-1}$ at pea stage (4-5 mm diameter berry size, two weeks after fruit set) and at veraision (approximately $10 \%$ of the berries of $50 \%$ of the clusters become soft and at colour break) hastened maturity and developed uniform berry colour compared to the control $\left(0.0 \mathrm{mg} \mathrm{L}^{-1} \mathrm{BRs}\right)$. The treatment also showed a positive impact on berry firmness. 
Salicylic acid: Salicylic acid (SA) or ortho-hydroxyl benzoic acid is an endogenous plant growth regulator of phenolic nature and classified as a growth promoter. It has been found to play a key role in the regulation of plant growth, development and enhance plant vigour under biotic and abiotic stresses (Hayat et al., 2010). It is an important secondary metabolite in grape berries and plays an essential role in determining berry quality such as colour, flavour, astringency and bitterness (Chamkha et al., 2003). Preharvest foliar spray of $1.5 \mathrm{mM} \mathrm{SA}$ at pea stage and at veraison hastened berry maturity by 3 to 5 days, and produced less compact bunches alongside larger berries in contrast to the control (Champa et al., 2014b). SA was effective in maintaining peel colour, firmness, anthocyanins, phenols and organoleptic properties during cold storage, while reducing weight loss, rachis browning and decay incidence of table grapes $c v$. Flame Seedless.

Horticultural maturity indices of table grapes: Grapes, which are grown in the Northern part of Sri Lanka are known to be of poor quality in contrast to the imported product, mainly because of the excessive sourness caused as a result of higher acidity. Since the grape berry is a non climacteric fruit with relatively low physiological activity, harvesting at correct maturity is mandatory for optimum flavour. Generally, the harvest date of grapes is determined by a total soluble solids (TSS) [or otherwise known as soluble solids content (SSC) or ${ }^{\circ}$ Brix] value of $14-17.5 \%$ depending on the cultivar and production area (Crisosto \& Smilanick, 1994). TSS of the grape juice is measured by placing the juice into the samplewell of a refractometer. According to Codex Standards (codexstan255-2007) for table grape maturity, the berries must be sufficiently developed and display satisfactory ripeness. In order to satisfy this requirement, the fruit must show a refractometric index of at least $16{ }^{\circ}$ Brix. Fruits with lower refractometric indices are accepted provided the sugar/acid ratio is at least equal to: (a) 20:1 if the Brix; level is greater than or equal to $12.5^{\circ}$ and less than $14^{\circ}$ Brix, (b) $18: 1$, if the Brix level is greater than or equal to $14^{\circ}$ and less than $16^{\circ} \mathrm{Brix}$. High consumer acceptance is attained for berries with high TSS or TSS/ TA ratio (TA: titratable acidity, measured with reference to tartaric acid equivalents by titrating the juice with $0.1 \mathrm{~N}$ sodium hydroxide) and this is termed as internal maturity index (IMI). Satisfactory berry firmness, lack of defects, free from decayed or cracked berries are also important factors for consumer acceptance. Furthermore, absence of stem browning, shrivelling, sunburn, dried berries and free from insect damages also equally affect consumer quality perception (Crisosto \& Smilanick, 1994).
Harvesting: As the grape bunch is highly susceptible to surface abrasions/bruises, the berries should not be touched when harvesting. Instead, the bunch should be held from the stem end and a gentle cut should be made above the holding position using secateurs so that, the natural bloom of berries can be retained. The harvested bunches should be kept in newspaper lined rigid containers such as plastic crates in a shady place until the produce is transported to packing shed. The harvested bunches may be field packed directly into shipping cartons, which reduces damage from repeated handling (Chervin et al., 2012). This method is practiced in some vine yards in the developed countries, where the picker usually trims the cluster to remove defective berries and obtain better bunch shape and size.

\section{Postharvest practices to maintain quality}

Although grape is a non climacteric fruit with relatively low physiological activity, it is a highly perishable commodity indicated by weight loss, softening, degradation of colour, berry shatter, rachis browning and decay development. Attempts have been made to extend the postharvest life of grapes while maintaining the quality through several strategies, which is discussed in detail below.

\section{Chemical treatments}

Polyamines: Polyamines (putrescine, spermidine and spermine) fulfil an array of roles in human cellular metabolism and in the synthesis of protein, RNA and DNA (Bardócz, 1995). The most important function of polyamines is to act as second messengers thereby mediating the action of all growth factors, thus they perform indispensable roles in human metabolism. According to Bardócz (1995) dietary polyamine intake has positively correlated with the protective roles against diseases. Most fruits and vegetables normally contain low levels of polyamines, except broccoli, cauliflower and citrus fruits (Eliassen et al., 2002). Reddy et al. (2008) reported that in grapes, putrescine was the major polyamine followed by spermidine and spermine. There was a general decline in the intensity of endogenous polyamines particularly spermine to undetectable levels during storage, especially in varieties with shorter shelf life. Postharvest application of polyamines has been demonstrated to influence the shelf life and quality of various fruits of both climacteric and non climacteric nature. The concentrations commonly used vary between 0.01 and $2 \mathrm{mM}$. 
Shiri et al. (2012) have reported that a combination of $1 \mathrm{mM}$ putrescine (a diamine) dip treatment followed by coating with $1 \%$ chitosan reduced the rate of weight loss, decay incidence, rachis browning and berry shattering in grape cv. Shahroudi stored at $0 \pm 1{ }^{\circ} \mathrm{C}, 90-95 \% \mathrm{RH}$ for up to 60 days. The treatment was also effective in maintaining phenolic compounds of the berries. Champa et al. (2014c; 2014d) have reported that prestorage dip treatment of $0.5 \mathrm{mM}$ putrescine or $0.5 \mathrm{mM}$ spermidine (a triamine) or $1.0 \mathrm{mM}$ spermine (a tetra amine) for 5 min maintained the quality and extended the shelf life of grape cv. Flame Seedless for up to 60 days in cold storage $\left(3-4{ }^{\circ} \mathrm{C}, 90-95 \% \mathrm{RH}\right)$. The treatment has effectively reduced the rate of berry softening, impaired degradation of peel colour $\left(L^{*}, C^{*}, h^{\circ}\right)$, stabilized anthocyanins and phenolic compounds and suppressed the activity of pectin methylesterase while reducing the rate of electrolyte leakage. Further, the treatment has effectively suppressed the reduction in sugar/acid ratio thus maintained the flavour attributes well.

Although there is an enormous number of research studies carried out on the use of polyamine as a potential postharvest tool to extend the shelf life of fresh horticultural products including mango, lemon, lime, peach and kiwi fruit etc., no commercial formulations are available.

\section{Packaging and use of sulfur dioxide generator pads}

Packaging plays an important role in maintaining the freshness while reducing the impact of handling on grape clusters. The clusters should be packed in corrugated fibre board (CFB) boxes of $4 \mathrm{~kg}$ capacity for transportation to distant markets (Figure 3). As grapes are highly susceptible to Botrytis infections during postharvest storage period, a $\mathrm{SO}_{2}$ generator pad, referred to as a grape guard, is placed on top of the grapes, which are packed in CFB boxes lined with LDPE film. It enables safe storage of grapes for up to 45 days in cold room $\left(0-2{ }^{\circ} \mathrm{C}, 90-95 \% \mathrm{RH}\right)$ (Mahajan et al., 2010). Size of the $\mathrm{SO}_{2}$ generator pad available in the market is $23.5 \times 32.0 \mathrm{~cm}$, which has been designed for commercial scale packing boxes of $4 \mathrm{~kg}$ capacity. The pad contains sodium metabisulphite as the active ingredient. The sodium metabisulphite in the pads reacts with available moisture to release $\mathrm{SO}_{2}$ gas. This gas then protects the grapes from fungal infection. Dualrelease pads give a rapid initial release of $\mathrm{SO}_{2}$ from a part of the pad while another part of the pad releases $\mathrm{SO}_{2}$ slowly over a period of $8-10$ weeks (Mustonen, 1992). Use of dual release $\mathrm{SO}_{2}$ generating pads in combination with a box plastic liner is advised when grapes are stored for periods longer than 10 days and during long periods of retail handling. The amount of $\mathrm{SO}_{2}$ released is affected by the temperature. Therefore, the effectiveness of these pads depends on good cold - chain management. One of the problems associated with $\mathrm{SO}_{2}$ treatments of grapes is the potential injury to the berries and rachises. Injured tissues first show bleaching of colour followed by sunken areas where accelerated water loss has occurred. Symptoms may also be seen around the cap stem, which slowly spreads over the berry. Additionally, treated berries sometimes develop a sulphurous taint (Chervin et al., 2012).

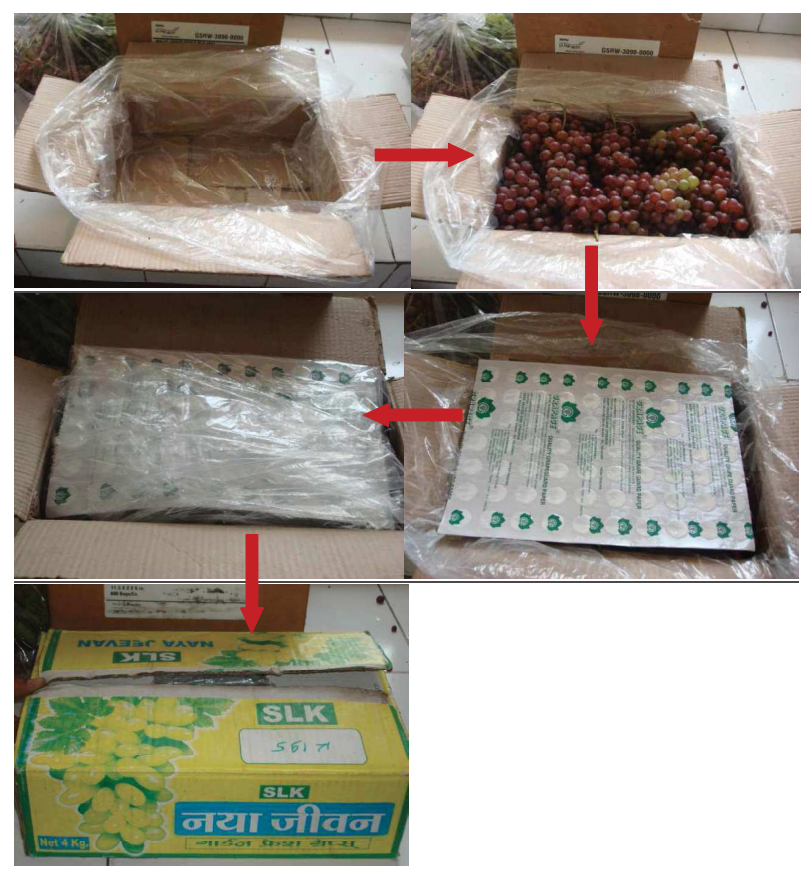

Figure 3: Packaging in corrugated fibre board boxes with polyethylene liner and a grape guard

\section{Storage}

Berry softening, shattering, stem browning and decay development are the main barriers for long term storage of grapes. However, if harvested at the correct maturity and packed (selected bunches which are free from any visible damages) in ventilated CFB boxes of $4 \mathrm{~kg}$ capacity, lined with LDPE containing one sheet of grape guard and stored at low temperature $\left(0-2{ }^{\circ} \mathrm{C}, 90-95 \%\right.$ $\mathrm{RH}$ ), the grapes can be kept for up to $45-50$ days with acceptable market quality (Mahajan et al., 2011), which can gain premium prices at the end of the season. 


\section{Acknowledgement}

The financial support by the Indian Council for Cultural Relations through the Commonwealth Academic Fellowship Programme 2010-11 for pursuing a $\mathrm{PhD}$ degree is highly acknowledged. Supervision and guidance offered by Dr M.I.S. Gill, Senior Horticulturist cum Head, Department of Fruit Science, Punjab Agricultural University, Ludhiana, Punjab, India and Dr B.V.C. Mahajan, Senior Horticulturist, Punjab Horticultural Postharvest Technology Center of Punjab Agricultural University, Ludhiana, Punjab, India are also acknowledged.

\section{REFERENCES}

1. Amiri M.E., Fallahi E. \& Mirjalili M. (2009). Effect of $\mathrm{ABA}$ or ethephon at veraison on the maturity and quality of Beidaneh Ghermez grapes. Journal of Horticultural Sciences and Biotechnology 84: 660 - 664 .

2. Amiri M.E., Fallahi E. \& Paresh S. (2010). Application of ethephon and ABA at $40 \%$ veraison advanced maturity and quality of Beidaneh Ghermez grape. Acta Horticulturae 884: $371-377$.

3. Anonymous (2010a). National campaign to motivate domestic food production 2008 - 2010. Proposed Plan for Presidential Task Force. Ministry of Agriculture Development and Agrarian Services, Rajamalwaththa Road, Battaramulla.

4. Anonymous (2010b). Package of Practices for Cultivation of Fruits, pp. 63 - 74. Punjab Agricultural University, Ludhiana, Punjab, India.

5. Anonymous (2012). The Wine Country. 2301, Redondo Avenue, Signal Hill, California, USA. Available at http:// www.tablegrapes.com, Accessed 13 March 2013.

6. Bardócz S. (1995). Polyamines in food and their consequences for food quality and human health. Trends in Food Science and Technology 61: 341 - 346.

7. Chamkha M., Cathala B., Cheynier V.\& Douillard R.(2003). Phenolic composition of champagnes from Chardonnay and Pinot Noir vintages. Journal of Agriculture and Food Chemistry 51: $3179-3184$.

DOI: http://dx.doi.org/10.1021/jf021105j

8. Champa W.A.H., Gill M.I.S., Mahajan B.V.C. \& Arora N.K. (2014a). Pre-harvest treatments of brassinosteroids on improving quality of table grapes (Vitis vinifera L.) cv. Flame Seedles. International Journal of Agricultural Sciences and Veterinary Medicine 2: 96 - 104.

9. Champa W.A.H., Gill M.I.S., Mahajan B.V.C. \& Arora N.K. (2014b). Preharvest salicylic acid treatments to improve quality and postharvest life of table grapes (Vitis vinifera L.) cv. Flame seedless. Journal of Food Science and Technology

DOI: http://dx.doi.org/10.1007/s13197-014-1422-7

10. Champa W.A.H., Gill M.I.S., Mahajan B.V.C. \& Arora N.K. (2014c). Postharvest treatment of polyamines maintains quality and extends shelf life of table grapes (Vitis vinifera
L.) cv. Flame Seedless. Postharvest Biology and Technology 91: $57-63$.

DOI: http://dx.doi.org/10.1016/j.postharvbio.2013.12.014

11. Champa W.A.H., Gill M.I.S., Mahajan B.V.C. \& Bedi S. (2014d). Exogenous treatment of spermine to maintain quality and extend postharvest life of table grapes (Vitis vinifera L.) $c v$. Flame Seedless under low temperature storage. LWT - Food Science and Technology 40 (1): $412-419$.

DOI: http://dx.doi.org/10.1016/j.lwt.2014.08.044

12. Chervin C., Aked A. \& Crisosto C.H. (2012). Grapes. Crop Post-Harvest Science and Technology (eds. D. Rees, G. Farrell \& J. Orchard), pp. 187 - 211. John Wiley and Sons, New Delhi, India.

DOI: http://dx.doi.org/10.1002/9781444354652.ch9

13. CODEX STAN 255-2007. Codex Standard for Table Grapes. Available at www.codexalimentarius.com, Accessed 27 March 2014.

14. Creasy G.L. \& Creasy L.L. (2009). Grapes. Crop Production Science in Horticulture 16, p. 295. CABI Head Office, Nosworthy Way, Wallingford, Oxfordshire, UK.

15. Crisosto C.H. \& Smilanick J.L. (1994). Table Grapes Postharvest Quality Maintenance Guidelines. Pomology Department, University of California, USA.

16. Eliassen K.A., Reistadb R., Risøena U. \& Rønninga H.F. (2002). Dietary polyamines. Food Chemistry 78: 273 - 280.

17. FAOstat (2012). FAO Statistical database. Food and Agricultural Organization of the United Nations. Available at $h t t p: / / w w w$ faostat.org/site/340/, Accessed 13 March 2013.

18. Gill M.I.S. \& Arora N.K. (2007). Grape Cultivation. Department of Fruit Science, Punjab Agricultural University, Ludhiana 141 004, Punjab, India.

19. Hayat Q., Hayat S., Irfan M. \& Ahmad A. (2010). Effect of exogenous Salicylic acid under changing environment: a review. Environment and Experimental Botany 68: 14-25. DOI: http://dx.doi.org/10.1016/j.envexpbot.2009.08.005

20. Mahajan B.V.C., Arora N.K., Gill M.I.S. \& Ghuman B.S. (2010). Studies on extending storage life of Flame Seedless grapes. Journal of Horticultural Sciences and Ornamental Plants 2: $88-92$.

21. Mahajan B.V.C., Gill M.I.S. \& Arora N.K. (2011). Postharvest handling of grapes. Advanced Production, Postharvest and Processing Technologies of Grapes. Department of Fruit Science, Punjab Agricultural University, Ludhiana, Punjab, India.

22. Mustonen H.M. (1992). The efficacy of a range of sulfur dioxide generating pads against Botrytis cincerea infection $\&$ on out-turn quality of Calmeria table grapes. Australian Journal of Experimental Agriculture 32: 389 - 393. DOI: http://dx.doi.org/10.1071/EA9920389

23. Peppi M.C., Fidelibus M.W. \& Dokoozlian N. (2006). Abscisic acid application timing and concentration affect firmness, pigmentation and colour of Flame Seedless grapes. Hortscience 41: 1440 - 1445.

24. Peppi M.C., Fidelibus M.W. \& Dokoozlian N. (2007). Application timing and concentration of ABA affect the quality of Red Globe grapes. Journal of Horticultural Sciences and Biotechnology 82: $304-310$. 
25. Reddy N.Y., Shankar B.V. \& Padmalatha V. (2008). Studies on the possible involvement of polyamines in the shelf life of grapes (Vitis vinifera L.). Acta Horticulturae 785: $457-463$.

26. Roberto S.R., Marinho de Assis A., Yamamoto L.Y., Miotto L.C.V., Sato A.J., Renata K. \& Werner G. (2012). Application timing and concentration of abscisic acid improve color of 'Benitaka' table grape. Scientia Horticulturae 142: $44-48$.

DOI: http://dx.doi.org/10.1016/j.scienta.2012.04.028

27. Shiri M.A., Ghasemnezhad M., Bakhshi D. \& Sarikhani H. (2012). Effect of postharvest putrescine application and chitosan coating on maintaining quality of table grape cv. Shahroudi during longterm storage. Journal of Food Processing and Preservation 37(5): 999 - 1007.

28. Symons G.M., Davies C., Shavrukov Y., Dry I.B., Mark R.T. \& Reid J.B. (2006). Grapes on steroids, Brassinosteroids are involved in grape berry ripening. Plant Physiology 140: $150-158$.

DOI: http://dx.doi.org/10.1104/pp.105.070706

29. Taiz L. \& Zeiger E. (2010). Ethylene. Plant Physiology, pp. 519 - 537. Sinauer Associates Inc., Publishers, Sunderland, Massachusetts, USA. 